\title{
Exploring VET Attractiveness in Greece through OAED Vocational Schools
}

\author{
Anastasios Athanasiadis \\ Open University of Cyprus \\ George Zarifis \\ Aristotle University of Thessaloniki \\ Greece
}

\begin{abstract}
Vocational Education and training (VET) is an educational route which ought to be designed so as to become an attractive choice. Improving the attractiveness of VET has been a major item on the European agenda for economic and social development. The European Parliament's Resolution urges the member states to promote the attractiveness of VET. The latter investigated through the opinions of 100 students of the vocational schools of $O A E D$ in a specific geographic region in Greece. The aim of the research is to measure the degree of acceptance of the policies set out in the European framework to improve the attractiveness of vocational education. The dependent variable is the attractiveness of vocational education provided through the schools of OAED and the independent variables are the policies focusing on European strategies to improve the attractiveness of VET. The first three positions were classified as related to the educational staff $(M=4.375, S=0.850)$, the training infrastructure $(M=4.345, S=0.951)$ and the provision of advisory support to students $(M=3.995, S=1.112)$.
\end{abstract}

Keywords: Vocational education, VET attractiveness, OAED

\section{Introduction}

A key vision of the European Union (EU) is to provide all European citizens with the basic knowledge and the technical skills they need to claim more and better jobs (European Commision, 2002). This vision combined with the fact that Europe is recovering from a serious financial crisis, which has changed the working environmental conditions and necessitates workers with different qualifications, leads us to the assumption that the key role is vocational education. Furthermore, if we consider the high levels of unemployment among young people, who are graduated from higher general education, then we are led to the conclusion that in order to satisfy the EU's vision, vocational education should be designed as an attractive option, through which citizens of a country will find clear choices that enable them to respond to the changing conditions of todays' knowledge economy(European Commision,2016). But how do European policies which are already aimed at enhancing the attractiveness of VET, will lead to an improvement of the image of vocational education in Greece?

In the last 25 years in the EU, efforts have been made at policy level to modernize VET curricula, teaching and training methods and to improve the transparency of its learning outcomes, so as to make it recognizable between different education systems (Gordon,2015), and to be chosen by young people and recognized by society as an alternative attractive educational route. The political discourse in Europe for VET has been shifted from the creation of a stable and solid framework to the supplying quality VET programs and to the linking of them to the labour market. Also because of the need for quality vocational education, the interest has now turned to the development of its human resources. The milestones of the European Union policies are included in table 1, from which derive the general axes for the improvement of VET attractiveness. 


\begin{tabular}{|l|l|}
\hline $\begin{array}{l}\text { Maastricht } \\
\text { communiqué } \\
(2004)\end{array}$ & $\begin{array}{l}\text { - Increasing public and/or private investment in VET } \\
\text { - Development of VET systems to meet the needs of people who are at a social disadvantage. } \\
\text { - Development of learning environment supplies. } \\
\text { - Promoting the continued development of VET trainers ' capacities. }\end{array}$ \\
\hline $\begin{array}{l}\text { Helsinki } \\
\text { Communiqué }\end{array}$ & $\begin{array}{l}\text { - Development of common European frameworks and tools for VET. } \\
\text { - Establishment of EUROPASSas a single framework for the transparency of qualifications and } \\
\text { competencies } \\
\text { - Working on the EQF,ECAVET, EQVET. }\end{array}$ \\
\hline $\begin{array}{l}\text { Bordeaux } \\
\text { communiqué } \\
(2008)\end{array}$ & $\begin{array}{l}\text { - Implementation of European tools and VET systems to promote cooperation to European and } \\
\text { - Creational level } \\
\text { - Consolidation of European cooperation procedures. }\end{array}$ \\
\hline $\begin{array}{l}\text { Bruges } \\
\text { communiqué } \\
(2010)\end{array}$ & $\begin{array}{l}\text { - Need for flexibility and high quality. } \\
\text { - Facilitating and encouraging transnational mobility of learners and teachers. }\end{array}$ \\
\hline $\begin{array}{l}\text { Riga } \\
\text { conclusions } \\
(2015)\end{array}$ & $\begin{array}{l}\text { - Promoting learning in the workplace. } \\
\text { - Development of quality assurance mechanisms in VET. } \\
\text { - Further strengthening of key competencies in VET curricula and giving more effective } \\
\text { opportunities of acquiring or developing these skills through initial and continuing VET. }\end{array}$ \\
& $\begin{array}{l}\text { - Provision of systematic approaches and opportunities for the initial and continuous professional } \\
\text { development of VET teachers. } \\
\text { - Offering consultancy into school and workplace environments. }\end{array}$ \\
\hline
\end{tabular}

Table 1. European policy priorities for VET(2004-2015).

\section{Attractiveness of vocational education}

Tchibozo (2009) states that attractiveness means that VET is of interest to people: they are knowledgeable about it, have curiosity about it, see it as part of the educational landscape and finally its graduates are prestigious. In a more demanding sense, it is the tendency for people to see the vocational path as a way to reach their personal goals or as a source of recruits for employers (p.5). The improvement of the attractiveness of VET can be achieved by adopting and imbedding into its policies and curricula, its stakeholders' views and priorities. Such priorities may increase VET attractiveness and are linked with the quality, the transparency, the accessibility and the provision of VET programs (Leneyet. al., 2004). Among the most important perspectives of attractiveness in the literature are the relevance to the labour market, the access to higher education, the high awareness, the status and the guidance of students (Watters,2009;Lavendels,Sitikovs\&Uhanova,2012). In the same line, personal development and the professional career of the graduates (Siikaniemi,2005), the supply of quality learning environments and finally the degree of attracting investment in it (Lasonen\&Gordon,2009) are the factors that affect VET attractiveness. Chankseliani et al. (2015)and Atkins and Flint (2015), highlighted the need to diffuse professional excellence and successes of VET graduates through skills competitions to up rate its image. Finally, another aspect of the VET attractiveness lies on its relationship with the general education and relates to the incomes (Brunello\&Rocco,2017)and the employability (Backes-Gellner\&Geel,2014)of its graduates in contrast to those of general education.

In Greece, according to Paidousi (2016), attractiveness of vocational education is interpreted through the perceptions of society regarding the negative school performance of students who are attending vocational schools and the low educational level of their families. Furthermore, attractiveness is altered from the limited opportunities for social mobility and the gender of the students. The key axes for enhancing the attractiveness of VET in Greece in line with the European Union's proposals (Cedefop,2014), can be classified in eight fields (table 2). These fields are the basis of our research methodology. 
1. Improve quality processes; adopt quality framework (including EQAVET)

4. Improve transition from VET to higher education

7. Revise,modernise IVETcurriculum
2. Improvements to guidance and counselling

5. Financial incentives

8. Improvements to/introduction of apprenticeship system
3. Campaigns to raise awareness

6. Improve teachers or teaching (also trainers)

Table 2. European Strategies for VET attractiveness in Greece

\section{Research methodology}

In Greece about 10,000 young people between 16-23 years old graduates of at least eleventh grade school (in Greece this stand for $\mathrm{A}^{\prime}$ Lyceum), choose to study in the vocational schools of the Manpower Employment Organization(O.A.E.D.). At this point we should mention that O.A.E.D. is the official public organization and its operation is based on the following three pillars: (i) promotion to employment; (ii) unemployment insurance and social protection of maternity and family; (iii) vocational education and training. Education is based on the apprenticeship system, which combines in-class vocational education with remunerated on-the-job training in businesses. In such system students aimed to acquire professional experience in real work conditions so as to facilitate their subsequent integration into the labour market (Fuller\&Unwin,2011). Consequently, it is tempting to measure the degree of influence of the attractiveness of vocational schools of OAED by the European policies that aimed to reinforce VET attractiveness, as there is not such a research approach in Greece. By enriching the available information regarding the factors that affect vocational education attractiveness, we assume to improve the policies that will eventually be implemented. Therefore, the purpose of this research approach is to measure the acceptance degree of the policies that European strategies sets out to improve the attractiveness of vocational education, through the student's opinions of OAED schools in the prefecture of Kozani in Western Macedonia. This research approach is a quantitative one. The dependent variable is "the attractiveness" of vocational education provided through the schools of O.E.A.D. and the independent variables are the eight individual dimensions in which European strategies are focused for improving the attractiveness of VET in Greece. The eight dimensions are explained by individual policies that make up concrete actions to enhance the attractiveness of VET (Figure 1).

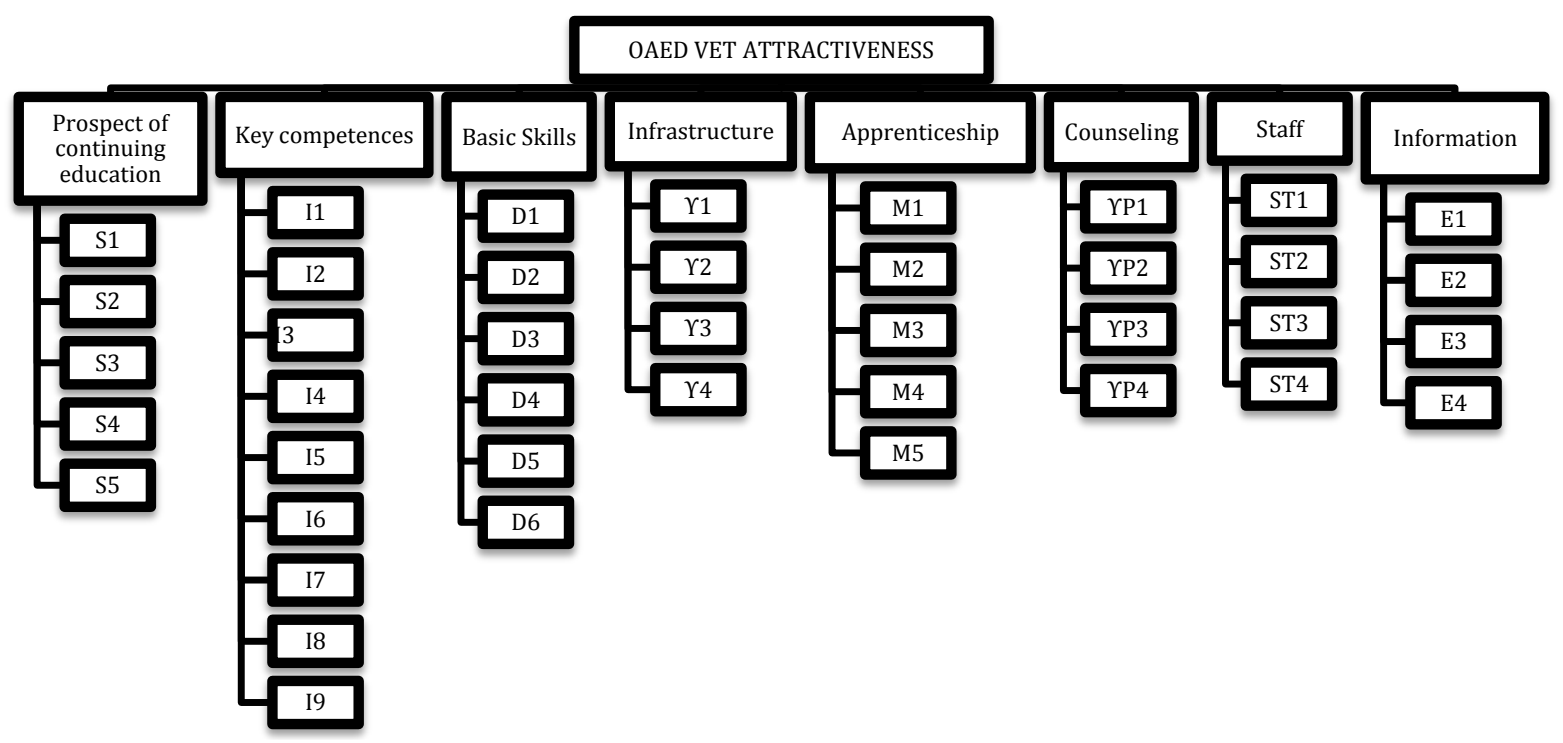

Figure 1.: Research Hypothesis 
The research questions based on the purpose of the research are the following:

To what extent does it affect the attractiveness of VET:

1. To provide students with the prospect of continuing education at next educational stages?

2. To include in its curriculum, lessons that enhance key competences?

3. The skills that students acquire during their studies?

4. The infrastructure and the necessary equipment of schools?

5. The apprenticeship system?

6. The provision of comprehensive monitoring of its graduates in the labour market and their support in the context of continuing education?

7. The professional and pedagogical competence of educational staff?

8. The structured information to the public and to the potential students?

\subsection{Participants}

We conduct a random stratified sampling approach in order to increase the accuracy of the measurements, as there was additional information about the population structure. Specifically, students of the OAED schools in the two cities of the prefecture of Kozani present the following structure based on their number and gender.

\begin{tabular}{|l|l|l|l|l|}
\hline & \multicolumn{3}{|l|}{ Kozani } & \multicolumn{3}{l|}{ Ptolemaida } \\
\hline Totalnumberofstudents & \multicolumn{5}{|l|}{375} \\
\hline Numberofstudents & 235 & $62.67 \%$ & 140 & $37.33 \%$ \\
\hline Males & 157 & $66.81 \%$ & 105 & $75.00 \%$ \\
\hline Females & 78 & $33.19 \%$ & 35 & $25.00 \%$ \\
\hline
\end{tabular}

Table 3. Population structure based on gender and number per school in Kozani prefecture

The sample size is based on the size of the population to which the research intends to generalize its results, the desired level of confidence, which was set at $95 \%$ and finally with the assumption that all potential participants are a representative sample for this study. We evaluate that all students are able to respond on the questions of the surveys as they are active members of this educational structure. The size of the participants was calculated by the national Australian statistical service tool, to satisfy the principle of representativeness (table 4).

\begin{tabular}{|l|l|}
\hline & Students \\
\hline Population size & 375 \\
\hline Sample size & $100(63$ Kozani -37 Ptolemaida $)$ \\
\hline Confidence level & $95 \%$ \\
\hline Standard error & 0.02585 \\
\hline
\end{tabular}

Table 4. Determination of sample size Source: http://www.nss.gov.au/nss/home.nsf/pages/sample + size + Calculator Participants' demographic characteristics are as follow. 


\begin{tabular}{|l|l|}
\hline Demographic variable & Rates \\
\hline Sex & $70 \%$ \\
\hline Male & 30 \\
\hline Female & \\
\hline $21-25$ & $39.0 \%$ \\
\hline $18-20$ & $61.0 \%$ \\
\hline Parents' EducationLevel & \\
\hline Compulsoryeducation & $19.0 \%$ \\
\hline Secondaryeducation & $66.0 \%$ \\
\hline Tertiaryeducation & $15.0 \%$ \\
\hline Parents' Occupation & \\
\hline Privateemployee & $31.0 \%$ \\
\hline Publicemployee & $23.0 \%$ \\
\hline Freelancer & $15.0 \%$ \\
\hline Farmer & $11.0 \%$ \\
\hline Retired & $5.0 \%$ \\
\hline Unemployed & $15.0 \%$ \\
\hline Familyincome & \\
\hline Until $€ 1000$ & $58.0 \%$ \\
\hline From 1001 to $€ 1500$ & $20.0 \%$ \\
\hline From 1501 to $€ 2000$ & $12.0 \%$ \\
\hline Over $€ 2001$ & $10.0 \%$ \\
\hline
\end{tabular}

Table 5. Population Demographics

Population demographics confirm the previous research data (Robert,2010;Paidousi,2016), which stated that students who choose VET schools are most males (70\%), they come from families with a low level of education (Compulsory education 19\%, Secondary education 66\%), and their parents are mainly private employees (31\%) with earnings up to $€ 1000$ per month (58\%). In addition, a significant proportion of students' families appear unemployed (15\%).

\subsection{Researchtool}

As a data collection tool, a closed-ended questionnaire wasdesignedwhich answered through a five-pointLikert scale.Attractiveness of the VET schools of OAED wasexamined through 41 proposals that express different aspects of the study concept. The selection of the proposals was based on the areas in which European policies focus on to improve the image of vocational education and training. The participants called to express their degree of agreement or disagreement in each of the proposals expressed in the questionnaire.Reliability was assessed by Cronbach a. In situations normally considered satisfactory the coefficient shows a value equal to or greater than 0.70 (Bryman,2015). In this empirical approach the coefficient was very high (Cronbacha=.922).At the same time all the dimensions of attractiveness interconnectboth with high and with statistically significant correlation.

\begin{tabular}{|c|c|c|c|c|c|c|c|c|}
\hline & D1 & D2 & D3 & D4 & D5 & D6 & D7 & D8 \\
\hline D1 & 1 &, $564^{* *}$ &, $385^{* *}$ &, $421^{*}$ &, $376^{*}$ &, $622^{*}$ &, $354^{*}$ &, $364^{*}$ \\
\hline D2 & & 1 &, $393^{* *}$ &, $353^{*}$ &, $393^{*}$ &, $580^{*}$ &, $411^{*}$ &, $486^{*}$ \\
\hline D3 & & & 1 &, $458^{*}$ &, $427^{*}$ &, $503^{*}$ &, $291^{*}$ & $465^{*}$ \\
\hline D4 & & & & 1 & $493^{*}$ &, $487^{*}$ &, $509^{*}$ & ,490* \\
\hline D5 & & & & & 1 &, $436^{*}$ &, $344^{*}$ & $431^{*}$ \\
\hline D6 & & & & & & 1 &, $472^{*}$ &, $567^{*}$ \\
\hline D7 & & & & & & & 1 &, $537^{*}$ \\
\hline D8 & & & & & & & & 1 \\
\hline
\end{tabular}

Table 6. Pearson correlation coefficients between the dimensions of the research tool 
Finally, according to the content validity,two academics and five professional training executives evaluated the measurement tool. In addition, it was confirmed that the research tool is directly related to the concept that is being investigated. Moreover, a pilot survey was made to formulate the questions so asto be understood by the participants.

\section{Results}

According to thestudents' opinions,all European Union policies affect VET attractiveness from a moderate (research question $1,2,3,5,8$ ) to a high degree (research question 4,6,7) level.

\begin{tabular}{|l|l|}
\hline Research questions & Degree of Influence \\
\hline $1^{\text {st }}:$ Continuation at next educational stages (D1) & Relatively high \\
\hline $2^{\text {nd }}$ Enrichment of curriculum(D2) & Medium \\
\hline $3^{\text {rd }}$ Learning outcomes (D3) & Medium \\
\hline $4^{\text {th }}$ VET infrastructure (D4) & High \\
\hline $5^{\text {th }}$ Apprenticeship (D5) & Relatively high \\
\hline $6^{\text {th }}$ Students Counselling (D6) & High \\
\hline $7^{\text {th }}$ VET Human resources (D7) & High \\
\hline $8^{\text {th }}$ Information to stakeholders (D8) & Medium \\
\hline
\end{tabular}

Table 7. Degree of influenced attractiveness of VET

Particularly, table 8 gathers total average scores of students' opinions per attractiveness policy, where is clearly stated that all of them are significant.

\begin{tabular}{|l|c|c|}
\hline Factor attractiveness of vocational education that related to & M & SD \\
\hline $\begin{array}{l}\text { D.1. The prospects that VET supports the continuation of its graduates, at the next educational } \\
\text { stages. }\end{array}$ & 3.732 & 1.185 \\
\hline D.2.The acquisition of key competences which will form an integral part of the curriculum. & 3.538 & 1.180 \\
\hline D.3.To provide its graduates with skills that will enable them to meet the demands of "new" jobs. & 3.593 & 1.094 \\
\hline D.4.The provision of proper infrastructures and equipment by VET providers. & 4.345 & 0.951 \\
\hline $\begin{array}{l}\text { D.5. The effective promotion of learning in workplaces. } \\
\text { D.6. The integrated monitoring of VET graduates in the labour market and supporting them in the } \\
\text { framework of continuing VET. }\end{array}$ & 3.648 & 1.155 \\
\hline D.7. Improving the quality of human resources in VET structures. & 1.112 \\
\hline $\begin{array}{l}\text { D.8. To intensify and systematically inform the public and the potential students in the field of } \\
\text { VET. }\end{array}$ & 3.375 & 0.850 \\
\hline
\end{tabular}

Table 8. Average scores of students ' opinions of OAED schools

Among the European policies that affect the attractiveness of the vocational schools of OAED, students distinguished those linked to the proper infrastructures during their apprenticeship and the proper linkage between their educationalsectorand the industry they are practice in. Furthermore, the quality of the educational staff and students mentoring so as to be effectively introduced into the labour market are the most important dimensions. 


\begin{tabular}{|c|c|c|c|}
\hline Attractiveness policy & Dimension & $\mathbf{M}$ & SD \\
\hline Adequate infrastructure in apprenticeships & D4 & 4.470 & 0.904 \\
\hline Professional experience of educational staff. & D7 & 4.470 & 0.771 \\
\hline Necessary materials (components, consumables); & D4 & 4.460 & 0.892 \\
\hline Cognitive ability of educational staff & D7 & 4.460 & 0.771 \\
\hline Laboratory equipment & D4 & 4.380 & 1.052 \\
\hline Pedagogical training of educational staff & D7 & 4.330 & 0.842 \\
\hline Skill recognition of traineeships & D1 & 4.310 & 0.950 \\
\hline Support (Ethics and technical) by the school's administrative staff & D7 & 4.240 & 1.016 \\
\hline $\begin{array}{l}\text { Acquisition in the apprenticeship of knowledge and skills requested } \\
\text { by the labour market }\end{array}$ & D5 & 4.210 & 0.935 \\
\hline $\begin{array}{l}\text { Providing counselling guidance on the prospects of residency prior } \\
\text { to registration }\end{array}$ & D6 & 4.140 & 1.092 \\
\hline Proper linkage between specialty and apprenticeship & D5 & 4.090 & 1.016 \\
\hline $\begin{array}{l}\text { Image and proper infrastructure of classrooms and communal } \\
\text { spaces }\end{array}$ & D4 & 4.070 & 0.956 \\
\hline Gaining knowledge of the labour market & D3 & 4.000 & 0.921 \\
\hline Guidance and counselling within the faculties for career prospects & D6 & 4.000 & 1.092 \\
\hline
\end{tabular}

\section{Discussion}

Table 9. Policies with high impact on OEAD school's attractiveness

Students stated that the most important factors that affect VET attractiveness are the teachers, indicating their pivotal role in the image of the OAED educational institution, followed by school infrastructure and counseling. Teachers' prior professional experience considered as a very important variable of school attractiveness $(M=4.500, S D=0.842)$. Similarly, students' counseling the administrative staff is also at the discretion of the participants an important attractiveness factor $(M=4.156, S D=1.273)$. These observations confirm educational policies that suggest personnel's continuous training in order to respond to modern educational challenges. Supporting teachers acquiring new competences such as collaborative skills, team teaching approaches and cooperative techniques are in need.

If educators had more time "planned intheir schedules for these activities, much more could be done to help young people thrive and learn in classrooms"'(Besson,et.al,2015, p.29)and this would increase the attractiveness of the schools they teach.

Furthermore, the infrastructures of the schools equally assess asa meaningful dimension which affects the attractiveness of OAED schools $(M=4.345, S D=0.951)$. The link between the quality of the educational outcomes and the quality of the school infrastructure has been extensively explored by the scientific community were the results affirmed that there is a statistically significant correlation between school infrastructures and the effectiveness of the training outcomes(OECD,2003; Barrett, et.al,2017).

Especially in vocational education where most of its curriculum includes laboratory courses and so it is very crucial to provide both the necessary infrastructures and the appropriate materials in order to implement effectively the educational process.

Offering counseling and support to the students was ranked third in the ranking scale of the variables that affect attractiveness of the OAED vocational schools $(M=3.995, S D=1.112)$. Career guidance is related to the quality and effectiveness of vocational education through two distinct stages. Before the selection of a program and during the vocational training (Watts, 2009). The advisory support functions effectively as an additional bridge between vocational education and the labour market (Field, et .al., 2009). It ensures that students are well informed about the conditions prevailing in the labour market. This means that they must be supported by highquality information which will be provided by specialized education executives and many times even by the employers themselves.

The dimension of apprenticeship as a variable of the attractiveness of vocational education ranked fifth by the students. The results show that students recognize the importance of professional knowledge they receive both in school and in workplaces. Students are taught in a different way at school because they can transform theoretical knowledge into applied based on the experiences they derive from the traineeship (Baartman,et. al., 2018). 
Finally, curriculum enrichment is being ranked last by the students $(M=3.538, S D=1.118)$, seeming that they are not prepared to accept such a reform. Curriculum enrichment is on high priority on the agenda of the European strategy for the upgrading of vocational education (Cedefop,2014). The schools of OAED operated in the past as T.E.E. (Technical Vocational Schools) and they had in their curricula, courses of general education, that is Greek, Math's, History etc. Nowadays students, who choose these vocational institutions, seek only the acquisition of technical experience and any effort to enrich the curriculum with additional courses is viewed with skepticism compared with the general secondary education.

\section{Conclusion}

Vocational education can contribute in improving social welfare in the sense of developing professional skills among young people and helping to reduce disparities between groups of a country's population (Powell,2012). Therefore, the need to promote it to young people, as a credible alternative educational route is undeniable. From our research it has emerged that the policies promoted by the European Union in terms of improving the image of vocational education are moving in the right direction. However, as in any other policy promoted by Europe to its state members, need to be adapted to the specific conditions governing the country of application. The European Union's proposals can therefore be a benchmark for the development of national strategies and common areas of cooperation between member states.

The vocational schools of OAED play a significant role in the Greek educational system, as they are the only schools that belong to the formal secondary educational level and offer two-year apprenticeship. However, they are treated as a structure of non-formal education and this affects negatively their image. This approach is incorrect and the reason, in our opinion, lies on the fact that their administrative responsibility belongs to the Ministry of Labour, when the entire educational system of the country is under the administration of the Ministry of Education. The latter promotes its vocational schools(EPAL) in which apprenticeships offered in some educational sectors for 9 months only, when schools of OAED offers a two-year apprenticeship in all sectors.

The present work focuses on the exploration of the policies that affect attractiveness of the vocational education through the schools of O.A.E.D. in the prefecture of Kozani, in western Macedonia. However, to extent the research conclusions, it must be expanded to all vocational schools of O.A.E.D. in Greece. Furthermore, in order to approach holistically all the structures of vocational education and training, it is proposed to extend the research to the other structures of vocational schools (EPAL) that are operating in the country with the simultaneous use of a qualitative research method.

In conclusion, it should be noted that special care should be taken to ensure that all the experience and know-how that has been developed in the OAED institutions through the 60 years of their operation, must be a point of reference for all the policy makers in the field of vocational education.

\section{References}

Atkins, L., \& Flint, K. J. (2015). Nothing changes: Perceptions of Vocational Education in England. International Journal of training Research, 13(1), 35-48.

Baartman, L. K. J., Kilbrink, N., and De Bruijn, E. (2018). VET students ' integration of knowledge engaged with in schoolbased and workplace-based learning environments in the Netherlands. Journal of Education and work, 1-14.

Backes-Gellner, U., \&Geel, R. (2014). A comparison of career success between graduates of vocational and academic tertiary education. Oxford Review of Education, 40(2), 266-291.

DOI: $10.1080 / 03054985.2014 .889602$

Barrett, P., Davies, F., Zhang, Y., and Barrett, L. (2017). The holistic impact of classroom spaces on learning in specific subjects. Environment and Behavior, 49(4), 425-451. https://doi.org/10.1177/0013916516648735.

Besson, B., Huber, J., Mompoint-Gaillard, P., and Rohmann, S. (2015). Education for change. Change for education. Strasbourg: Council of Europe.

Brunello, G., and Rocco, L. (2017). The effects of vocational education on adult skills, Employment And wages: What can we learn from PIAAC? Series, 8(4), 315. DOI: 10.1007/s13209-017 -0163-Z

Bryman, A. (2015). Social Research Methods. Oxford University Press.

Cedefop(2014). Attractiveness of Initial Vocational education and training: identifying what matters. Luxembourg: Publications Office. Cedefop Reference series. Www.cedefop.europa.eu/EN/Files/5539_en.pdf

Chankseliani, M., James Relly, S., andLaczik, A. (2015). Overcoming vocational Prejudice: How can skills competitions improve the attractiveness of vocational education and training in the UK? British Educational Research Journal. 
European Commission (2002).Declaration of the European Ministers of vocational education and training, and the European Commission, convened in Copenhagen on 29 and 30 November 2002, on enhanced European cooperation in vocational education and training, Brussels, European Commission.

European Commission(2004). Maastricht communique on the Future Priorities of enhanced European Cooperation in Vocational Education and Training (VET). Review of the Copenhagen Declaration of 30 November 2002 Online:Http://ec.europa.eu/education/news/ip/docs/maastricht_com_en.pdf

European Commission (2006).The Helsinki communiqué on enhanced European cooperation in vocational education and training: Communiqué of the European Ministers of vocational education and training, the European social partners and the European Commission, convened in Helsinki on 5 December 2006Brussels, European Commission.

European Commission (2008).The Bordeaux Communiqué on Enhanced European Cooperation in Vocational Education and Training. Communiqué of the European Ministers for Vocational Education and Training, the European Social Partners and the European Commission, meeting in Bordeaux on 25 November 2008 To Review the Priorities and Strategies of the Copenhagen process, Brussels, European Commission.

European Commission (2010). The Bruges Communiqué on enhanced European cooperation in vocational education and training for the period 2011-2020. In Communiqué of the European Ministers for Vocational Education and Training, the European Social Partners and the European Commission, meeting in Bruges on (Vol. 7, pp. 20112020).

European Commission (2015). Developing skills for the labour market: the Riga conclusions: European cooperation in vocational education and training 2015-2020.

European Commission, (2016). Enhanced EU cooperation on vocational education and training. Retrieved Fromhttp://eurlex.europa.eu/legal-content/EL/ALL/?uri=LEGISSUM:ef0018 (In Greek)

Field, S., Hoeckel,K. Kis, V., andKuczera, M. (2009). Learning for jobs: OECD Policy review of Vocational education and training: initial Report. Paris: OECD.

Fuller, A., \& Unwin, L. (2011). Apprenticeship as an evolving model of learning. Journal of Vocational Education and training, 63(3), 261-266.

Gordon, J. (2015). Glimpsing the Future in the Past: VET in Europe. European Journal of Education, 50(4), 440-460. DOI: 10.1111/Ejed. 12151

Lasonen, J., and Gordon, J. (2009). Improving the attractiveness and image of VET. Modernising Vocational education and training: fourth report on vocational training research in Europe: Background report, 3, 15-88.

Lavendels J. Sitikovs, V., and Uhanova, M. (2012). Influence of socio-demographic characteristics to attractiveness and Success of Initial Vocational Education And Training In Latvia. Procedia-Social and Behavioral Sciences, 55, 756765.

Leney, T., QCA, L., \& UK BIBB, B. (2004). Achieving the Lisbon goal: the contribution of VET. Https://www.bibb.de/dokumente/pdf/a13_lisbon_goals_final

OECD (2003). Student performance and physical infrastructure. Retrieved August 25, 2018 fromHttp://www.oecd.org/education/innovation-education/studentperformanceandphysicalinfrastructure.htm

Paidousi, CH. (2016). Attractiveness of vocational education: social and economic Gendered Dimensions. National Institute of Labour and Human resources (In Greek).

Powell, L. (2012). Reimagining the purpose of VET - expanding the capability to aspire in South African Further Education and training students. International Journal of Educational Development, 32(5), 643-653.

Robert, P. (2010). Social origin, school choice, and student performance. Educational Research and Evaluation, 16(2), 107129.

Siikaniemi, L. (2005). Magnetic Metal-Toward a Model for Satisfaction of Education and Career in Vocational Upper Secondary education and training of Machinery and metal Technology in the Lahti Region. Tampere University Press.

Tchibozo, G. (2009). Improving attractiveness of initialvocational education andtraining: some observations on the EU experience. Paper delivered at theconference Lifelong learning revisited: what next? University of Stirling, 23 to26 June 2009.

Watters, E. (2009). Making Initial vocational education and training more attractive for learners, The European Network on Quality Assurance in vocational education and Training (Enqa_vet). Available from www.deqaet.de/_media/TG_Report_MIVMA.

Watts, A. G. (2009). The relationship of career guidance to VET. National Institute for Careers Education and Counselling (OECD Report). Cambridge: OECD. Retrieved from www.OECD.Org/Edu/Skills-Beyond-School/44246 